DOI: $10.12731 / 2658-6649-2020-12-5-179-191$

UDC 581.1:581.19

\title{
INFLUENCE OF HIGH TEMPERATURES ON HEAT TOLERANCE AND SYNTHESIS OF HEAT SHOCK PROTEINS IN SPRING WHEAT AT THE INITIAL STAGES OF DEVELOPMENT
}

\author{
Fedotova O.A., Polyakova E.A., Grabelnykh O.I.
}

Wheat is one of the agricultural crops that is subjected to temperature stress during ontogenesis and it is especially sensitive to action of the stress at the initial stages of wheat development. High temperatures restrict of growth, development and plant productivity. However, plants can to acclimate to temperature stress and have the adaptive mechanisms at the cellular and molecular levels. One of this adaptive mechanism is an increase of the synthesis of the heat shock proteins (HSPs), which functions are very important and various.

The aim of this study was to determine the influence of different heat treatments ( 37 and $39{ }^{\circ} \mathrm{C}$ for $1,3,6,24 \mathrm{~h}$ and $50{ }^{\circ} \mathrm{C}$ for $1,3,5 \mathrm{~h}$ ) on the heat tolerance in spring wheat seedlings (Triticum aestivum L.) and synthesis of the HSPs (101, 70, 60 and $16.9 \mathrm{kDa})$ in shoots of the 4-day-old seedlings and leaves of the 8-day-old seedlings.

Based on the findings, it is concluded that the 4-day-old and 8-day-old spring wheat seedlings are characterized by a similar response to heat stress at $50{ }^{\circ} \mathrm{C}$, however, 4-day-old seedlings are more resistant in the initial period of stress influence. The exposures at 37 and $39^{\circ} \mathrm{C}$ are suitable for acclimation of spring wheat at the initial stages of development (the 4-day and 8-day-old seedlings). These temperatures lead to a similar trend in the heat resistance of seedlings and the synthesis of HSPs in shoots and leaves. At the same time the content of HSP16.9 depends on the developmental stage of wheat. It is noted the synthesis of HSP16.9 in shoots, but not in leaves under normal conditions. It is concluded that the heat acclimation of the 8-day-old seedlings is a longer process (6-24 h of exposure at 37 and $39{ }^{\circ} \mathrm{C}$ ) compared with the 4-day-old seedlings (3-6 h of exposure at 37 and $39^{\circ} \mathrm{C}$ ).

Keywords: Triticum aestivum L.; heat shock proteins; acclimation; seedlings; shoots; leaves; high temperature; heat tolerance. 


\title{
ВЛИЯНИЕ ВЫСОКИХ ТЕМПЕРАТУР НА ТЕПЛОУСТОЙЧИВОСТЬ И СИНТЕЗ БЕЛКОВ ТЕПЛОВОГО ШОКА В ЯРОВОЙ ПШЕНИЦЕ НА НАЧАЛЬНЫХ СТАДИЯХ РАЗВИТИЯ
}

\author{
Федотова О.А., Полякова Е.А., Грабельных О.И.
}

Пшеница одна из сельскохозяйственных культур, которая подвергается действию температурного стресса в течение онтогенеза и особенно чувствительна к действию стресса на начальных стадиях её развития. Высокие температуры ограничивают рост, развитие и продуктивность растений. Однако, растения могут адаптироваться к температурному стрессу и имеют адаптивные механизмы на клеточном и молекулярном уровнях. Одним из таких адаптивных механизмов является увеличение синтеза белков теплового шока (БТШ), функиии которых очень важны и разнообразны.

Целью данной работы было изучить влияние различных тепловых обработок (37 и $39{ }^{\circ} \mathrm{C}$ в течение $1,3,6,24$ ч и $50{ }^{\circ} \mathrm{C}$ в течение $1,3,5$ ч) на теплоустойчивость проростков яровой пшениць (Triticum aestivum L.) и синтез БТШ (101, 70, 60 и 16.9 кДа) в побегах 4-х суточных и листьях 8-ми суточных проростков.

На основании полученных данных сделан вывод, что 4-х суточные $и$ 8-ми суточные проростки яровой пшеницы характеризуются схожей реакцией на тепловой стресс при $50{ }^{\circ} \mathrm{C}$, однако 4-х суточные проростки более устойчивы в начальный период стрессового воздействия. Воздействие температурами 37 и $39{ }^{\circ} \mathrm{C}$ подходят для адаптации яровой пшеницы на начальных стадиях её развития (4-х суточные и 8-ми суточные проростки). Эти температуры приводят к схожей тенденции в синтезе БТШ в побегах и листьях. В тоже время, содержание БТШ16.9 зависит от стадии развития пшеницы. В нормальных условиях был отмечен синтез БТШ16.9 в побегах, но не в листьях. Сделано заключение, что адаптация 8-ми суточных проростков более длительный процесс (6-24 ч воздействия 37 и $\left.39^{\circ} \mathrm{C}\right)$ по сравнению с 4-х суточными проростками (3-6 ч воздействия 37 и $39^{\circ} \mathrm{C}$ ).

Ключевые слова: Triticum aestivum L.; белки теплового шока; aдаnтация; проростки; побеги; листья; высокая температура; теплоустойчивость. 


\section{Introduction}

Wheat is one of the agricultural crops that is subjected to temperature stress and it is very sensitive to action of the heat stress during ontogenesis at the stages of seedling germination and leaf formation, anthesis and grain filling. On these stages of development, the high temperatures restrict of growth, development and wheat productivity [1]. The normal temperature of vegetative development of wheat is reported to be $20-30{ }^{\circ} \mathrm{C}$, and the adverse of the stress effect depends on the magnitude, timing and the duration of stressful influence [2]. However, plants can to adapt to stress and for heat tolerance is required different changes on physiological, biochemical and molecular levels. The synthesis of heat shock proteins (HSPs) is one of essential component of the plant response to elevated temperatures and thermotolerance [3-8]. The heat resistant depends on the synthesis of HSPs that improve different processes, such as photosynthesis, respiration, membrane stability, water use efficiency, assimilate partitioning and can to use the reactive oxygen species as a signal molecule and regulate the activity of the antioxidant enzymes [9]. The principal heat shock proteins are grouped into five conserved classes: HSP100, HSP90, HSP70, HSP60, and the small heat shock proteins (sHSPs) $[3,9]$. HSP16.9 is a sHSPs, that belongs to a family of class I of HSP20 family. HSP16.9 may interact with many essential polypeptides in a manner similar to HSP90 [3, 10]. sHSPs form a high molecular weight oligomeric complexes which may to serve as cellular matrix for stabilization of unfolded proteins and for its function are needed HSP100, HSP70 $[3,6,9]$. HSP60 perform the function of ATP-dependent specialized folding machinery [3]. HSP100 is responsible for ATP-dependent dissociation and degradation of aggregate protein $[3,11]$. HSP70 is responsible for primary stabilization of newly formed proteins $[3,12]$. It is known that the low-molecular-weight HSPs can protect the chloroplasts and the mitochondria from heat damage [13]. The chloroplastic and mitochondrial sHSPs are considered to play an important role in heat tolerance [6].

The responses of plants to high temperatures are very complex including different physiological and metabolic changes that effect on the plant development and the interactions on cellular and molecular levels. Therefore, little research has systematically compared the effects of heat elevated and stressful temperatures of various durations in various developmental phases of wheat [2]. Many works are devoted to the study of the influence of high elevated and stressful temperatures at the level of wheat flowering and grain filling, but not at the initial stages of wheat development. In this connection, the purpose of this work was to determine compared analyze of the influence of elevated (37 
and $39^{\circ} \mathrm{C}$ for $\left.1,3,6,24 \mathrm{~h}\right)$ and stressful $\left(50^{\circ} \mathrm{C}\right.$ for $\left.1,3,5 \mathrm{~h}\right)$ temperatures on the heat resistant (Triticum aestivum L.) and synthesis of the HSPs (101, 70, 60 and $16.9 \mathrm{kDa}$ ) in wheat at the initial stages of development.

\section{Samples and Research Methods}

We used the 4-day-old and 8-day-old seedlings of spring wheat (Triticum aestivum L.) variety "Novosibirskaya 29". The 2-day-old seedlings were transferred into $3-\mathrm{dm}^{3}$ boxes with solution a half-strength Knop medium and were grown in a KBWF 400 chamber at $23{ }^{\circ} \mathrm{C} / 20^{\circ} \mathrm{C}(16 \mathrm{~h}$ day / $8 \mathrm{~h}$ night $)$ and illumination $200 \mu \mathrm{mol}$ (photon) $\mathrm{m}^{-2} \mathrm{~s}^{-1}$ photosynthetic active radiation.

For heat acclimation, control seedlings into $3-\mathrm{dm}^{3}$ boxes were transferred in a KBWF 240 chamber at 37 or $39^{\circ} \mathrm{C}$ for $1,3,6,24 \mathrm{~h}$ under light conditions. For heat stress treatment, control seedlings into $3-\mathrm{dm}^{3}$ boxes were transferred in a KBWF 240 chamber and were subjected to heat stress at $50{ }^{\circ} \mathrm{C}$ for $1-5 \mathrm{~h}$ under light conditions. Cultivation and temperature treatments were carried out in Binder chambers (Tuttlingen, Germany) of the experimental station "Fitotron" SIPPB SB RAS.

The effectiveness of acclimation is assessed by the accumulation of heat shock proteins in the shoots of 4-day-old seedlings and leaves of 8-day-old plants spring wheat after heat treatments.

The heat resistant was studded using conductivity meters HI 8734 (Hanna Instruments Inc., Nusfalau, Romania). The yield of electrolytes from the leaf and shoot cells (V, \%) was calculated by the formula: $\mathrm{V}=100(\mathrm{Lt} / \mathrm{Lk})$, where $\mathrm{Lt}$ is the electrical conductivity of the sample after heat treatment, Lk is the conductivity of the same sample after $15 \mathrm{~min}$ of the boiling.

Content of the heat shock proteins in shoot and leaves of seedlings were investigated by $1 D$ SDS-PAGE electrophoresis with using the Mini-PROTEAN III Electrophoretic Cell (Bio-Rad, USA). The total protein from green shoots and leaves was extracted according with Borovik and Grabelnych [14]. After SDS-PAGE, the separated proteins were transferred on a nitrocellulose membrane (GE Healthcare, Freiburg, Germany) by the Mini Trans-Blot (Bio-Rad, USA). Then the HSPs were visualized with a BCIP-T/NBT alkaline phosphate system (Thermo Scientific, Vilnius, Lithuania). It was used the following antibodies: anti-HSP101 (AS07 253, Agrisera, Vännäs, Sweden), anti-HSP70/ Hsc70 (SPA-820, StressGen, Victoria, Canada), anti-HSP60 (H1830-77B, US Biological, Salem, MA, USA), anti-HSP16.9 (AS12 2570, Agrisera, Vännäs, Sweden), anti-Actin (AS13 2640, Agrisera, Vännäs, Sweden), and secondary antibodies conjugated with alkaline phosphatase (Agrisera, Vännäs, Sweden). 
The statistical significance of differences for the comparison of groups was determined by ANOVA with using program of SigmaPlot14.0 (Systat Software Inc. (SSI), USA). It was dune at least three independent experiments. Data are presented as mean \pm SD (standard deviation of the mean) and as median with percentiles (75th percentile and 25 th percentile). The differences at $p<0.05$ were considered statistically significant.

\section{Research Results and Discussion}

Since wheat is sensitive to high temperatures during stages of seedling germination and leaf formation, it was selected these stages as 4-day and 8-day-old seedlings, respectively (fig. 1).

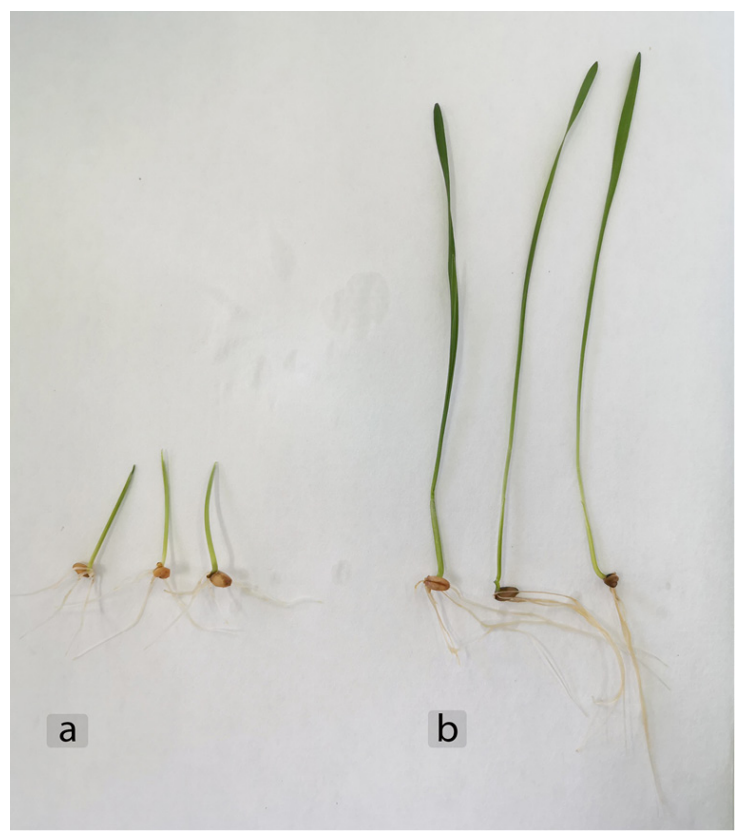

Fig. 1. The seedlings of spring wheat.

Note: $\mathrm{a}$ - the 4-day-old seedlings; $\mathrm{b}$ - the 8 -day-old seedlings of spring wheat

The heat resistance of seedlings was assessed by the yield of electrolytes from cells into water. It should be noted that the yield of electrolytes in control samples is different and it is much higher in shoots of 4-day-old seedlings compared with the leaves of 8-day-old seedlings (fig. 2). 

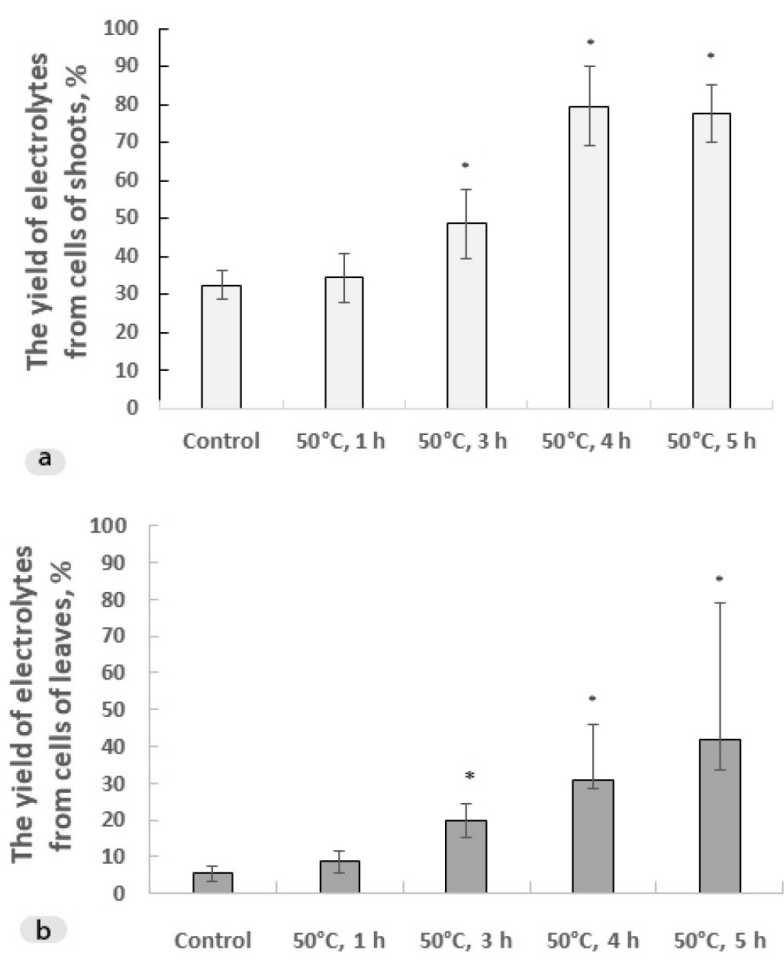

Fig. 2. The influence of heat stress $\left(50^{\circ} \mathrm{C}\right)$ on the heat resistant of spring wheat seedlings.

Note: $\mathrm{a}$ - the 4-day-old seedlings; $\mathrm{b}$ - the 8-day-old seedlings of spring wheat. The data are presented as mean \pm SD for $a$ and median and percentiles $\left(75^{\text {th }}\right.$ percentile and $25^{\text {th }}$ percentile) for $b . n=3$. ${ }^{*}$ The differences between the control and heat treatments are statistically significant; $P<0.05$.

The heat shock at $50{ }^{\circ} \mathrm{C}$ (from 1 to $5 \mathrm{~h}$ ) resulted in the increase of yield of electrolytes from cells of the leaves and shoots. At the same time the content of electrolytes from shoot cells was significantly lower compared with the leaves (fig. 2). As shown in Fig. 2, the heat stress at $50{ }^{\circ} \mathrm{C}$ for $3 \mathrm{~h}$ resulted in the increase of yield of electrolytes from cells of shoots and leaves by 1.5 and 3-fold, respectively. This indicates that the 4-old-day seedlings are more resistant to heat stress at initial period of influence at $50{ }^{\circ} \mathrm{C}$. It is likely that this increased heat resistance deals with a higher level of carbohydrates, HSPs and other pro- 
tective compound that are accumulated under action of high temperature in seedlings [6, 15-17].

For next stage of the work, it was selected the temperatures of heat acclimation $\left(37\right.$ and $\left.39^{\circ} \mathrm{C}\right)$ with an exposure interval $(1,3,6,24 \mathrm{~h})$ which was estimated by heat resistant of seedlings and synthesis of HSPs in shoots and leaves (fig. 3 ).
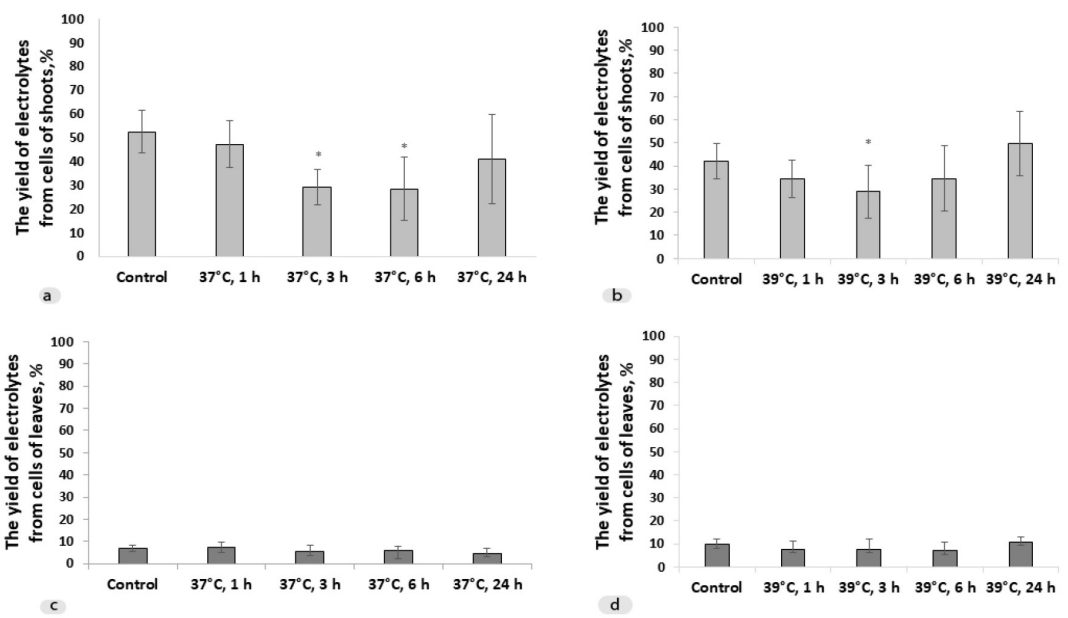

Fig. 3. The influence of heat treatments $\left(37\right.$ and $\left.39^{\circ} \mathrm{C}\right)$ on the heat resistant of spring wheat seedlings.

Note: $a, b$ - the 4-day-old seedlings; $c, d$ - the 8-day-old seedlings of spring wheat. The data are presented as mean \pm SD for a,b and median and percentiles (75th percentile and 25th percentile) for $\mathrm{c}, \mathrm{d} . \mathrm{n}=3$. * The differences between the control and heat treatments are statistically significant; $\mathrm{P}<0.05$.

The increase in the duration of the time exposed at 37 and $39^{\circ} \mathrm{C}$ (from 1 to $24 \mathrm{~h}$ ) was not accompanied by an increase the yield of electrolytes from shoot and leaves cells (fig. 3).

The induction of HSP synthesis is classical plant response to high temperatures and it is an essential component of the plant heat acclimation and thermotolerance $[3,5,7,9,18]$. The efficiency of heat acclimation for 4-day-old and 8-day-old plants was assessed by the synthesis of HSPs with molecular weight of 101, 70, 60 and $16.9 \mathrm{kDa}$ in shoots and leaves of the seedlings (figs. 4 and 5). It was noted that the synthesis of HSP16.9 is observed only in shoots of the 4-day-old seedlings, but not in leaves of the 8-day-old seedlings at the control conditions (fig. 4). 

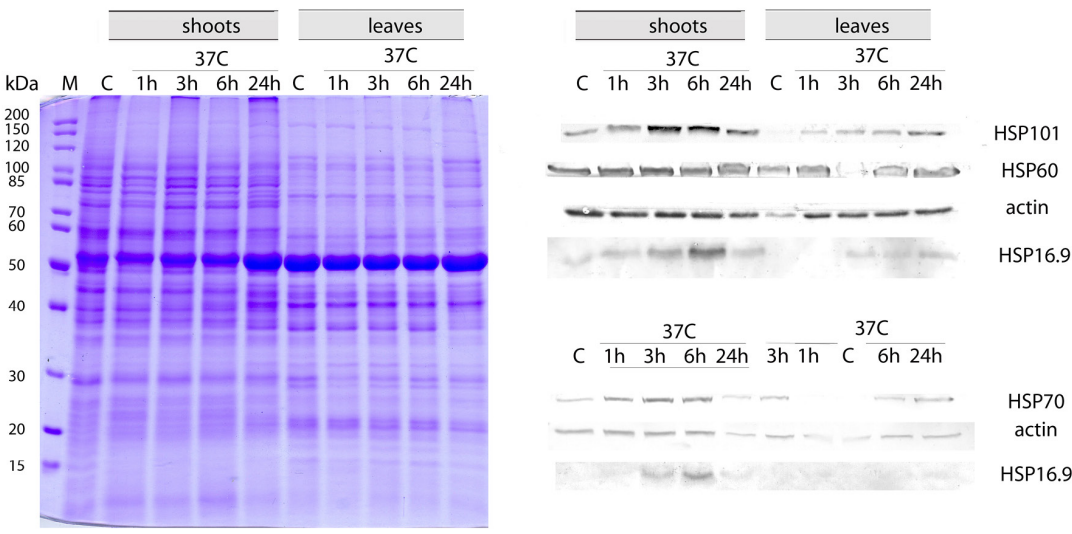

HSP16.9

Fig. 4. Effect of the heat treatments $\left(37^{\circ} \mathrm{C}\right.$ for 1 to $\left.24 \mathrm{~h}\right)$ on the HSPs content in the spring wheat seedlings.

Note: $\mathrm{C}$ - control seedlings; $\mathrm{M}$ - the protein markers; 1 D SDS-PAGE separation of total proteins followed by immunoblotting with antibodies against HSPs and actin that were visualized with a BCIP-T/NBT alkaline phosphate system are presented from left to right. $\mathrm{n}=3$.
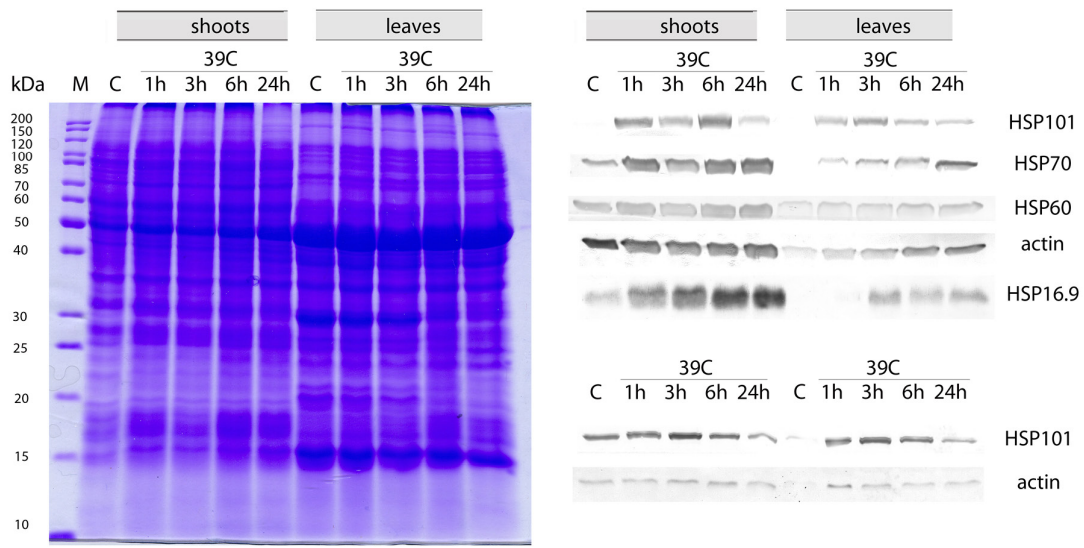

Fig. 5. Effect of the heat treatments $\left(39^{\circ} \mathrm{C}\right.$ for 1 to $\left.24 \mathrm{~h}\right)$ on the HSPs content in the spring wheat seedlings.

Note: $\mathrm{C}$ - control seedlings; $\mathrm{M}$ - the protein markers; 1 D SDS-PAGE separation of total proteins followed by immunoblotting with antibodies against HSPs and actin that were visualized with a BCIP-T/NBT alkaline phosphate system are presented from left to right. $\mathrm{n}=3$. 
The changes in the HSPs content in spring wheat seedlings after heat treatments is observed (figs. 4 and 5). It is known that under high temperature the HSP100, HSP90, HSP70 and HSP20 (or small HSPs) are expressed in maximal amounts [6]. The increase in the duration of time exposed to $37^{\circ} \mathrm{C}$ (from 1 to $24 \mathrm{~h}$ ) was accompanied by an increase in the HSP101 content in both shoots and leaves of seedlings of spring wheat (fig. 4). The higher induction of the synthesis of HSP70 is detected under heat exposure at $37^{\circ} \mathrm{C}$ for $3-6 \mathrm{~h}$ in shoots and at $37^{\circ} \mathrm{C}$ for $24 \mathrm{~h}$ in leaves. As shown in Fig. 4, the higher induction of the synthesis of HSP 16.9 is detected under heat exposure at $37^{\circ} \mathrm{C}$ for $6 \mathrm{~h}$ in shoots and at $37{ }^{\circ} \mathrm{C}$ for $24 \mathrm{~h}$ in leaves.

Also as shown in Fig. 4, the content of HSP16.9 was detected only in shoots, but not in leaves at the control conditions (fig. 5). At the same time, for the higher content of HSP16.9 is required under a prolonged exposure of $39^{\circ} \mathrm{C}$ in both 4-day-old and 8-day-old seedlings (fig. 5).

As shown in Fig. 5, the higher induction of the synthesis of HSP70 is detected under heat exposure at $39{ }^{\circ} \mathrm{C}$ for $1-24 \mathrm{~h}$ in shoots and at $39{ }^{\circ} \mathrm{C}$ for $24 \mathrm{~h}$ in leaves. The increase in the duration of time exposed to $39{ }^{\circ} \mathrm{C}$ (from 3 to 6 h) was accompanied by an increase in the HSP101 content in both shoots and leaves of seedlings of spring wheat (fig. 5). Based on the research conducted, it was supposed that synthesis of HSP16.9 depends on on the developmental stage of spring wheat. It is known that some sHSPs are highly-expressed in embryogenic tissues and growing fruits [6] and not only under stress condition, but in normal development $[8,9]$.

\section{Conclusion}

It was concluded that the ability of wheat to acclimation depends on duration of the exposure at temperatures $\left(37\right.$ and $\left.39^{\circ} \mathrm{C}\right)$ and stages of the wheat development. The thermotolerance also depends on the stages of wheat development. The important role of the heat shock proteins (especially of small heat shock proteins) in the heat acclimation of wheat at the initial stages of its development was revealed.

\section{Conflict of interest information}

We have no conflict of interest to declare.

\section{Sponsorship information}

This work was carried out with the financial support of the grant of the President of the Russian Federation No. MK-1720.2020.4. 


\section{Acknowledgments}

This research was done using the equipment of The Core Facilities Center "Bioanalitika" and the collections of The Core Facilities Center "Bioresource Center" at The Siberian Institute of Plant Physiology and Biochemistry SB RAS (Irkutsk, Russia).

\section{References}

1. Abdelrahman M., Burritt D.J, Gupta A., Tsujimoto H., Tran L.P. Heat stress effects on source-sink relationships and metabolome dynamics in wheat. $J$ Exp Bot, 2020, vol. 7, pp. 543-554, doi: 10.1093/jxb/erz296

2. Balla K., Karsa I., Bónis P., Kiss T., Berki Z., Horváth Á, Mayer M., Bencze S., Veisz O. Heat stress responses in a large set of winter wheat cultivars (Triticum aestivum L.) depend on the timing and duration of stress. PLoS One, 2019, vol.14(9): e0222639, doi: 10.1371/journal.pone.0222639

3. Hasanuzzaman M., Nahar K., Alam M.M., Roychowdhury R., Fujita M. Physiological, biochemical, and molecular mechanisms of heat stress tolerance in plants. Int. J. Mol. Sci., 2013, vol. 14, pp. 9643-9684, doi: 10.3390/ ijms14059643

4. Jacob P., Hirt H., Bendahmane A. The heat-shock protein/chaperone network and multiple stress resistance. Plant Biotechnol J, 2017, vol. 15, pp. 405-414, doi: $10.1111 /$ pbi.12659

5. Rizhsky L., Liang H., Shuman J., Shulaev V., Davletova S., Mittler R. When defense pathways collide. The response of Arabidopsis to a combination of drought and heat stress. Plant Physiol., 2004, vol. 134, pp. 1683-1696, doi: 10.1104/pp.103.033431

6. Sarkar N.K., Kim Y., Grover A. Rice sHsp genes: genomic organization and expression profiling under stress and development. BMC Genomics, 2009, vol. 10: 393, doi: 10.1186/1471-2164-10-393

7. Vierling E. The roles of heat shock proteins in plants. Annu. Rev. Plant Physiol. Plant Mol. Biol., 1991, vol. 42, pp. 579-620, doi: 10.1146/annurev. pp.42.060191.003051

8. Waters E.R., Aevermann B.D., Sanders-Reed Z. Comparative analysis of the small heat shock proteins in three angiosperm genomes identifies new subfamilies and reveals diverse evolutionary patterns. Cell Stress Chaperones, 2008, vol. 13, pp. 127-142, doi:10.1007/s12192-008-0023-7

9. U1 Haq S., Khan A., Ali M., Khattak A.M., Gai W., Zhang H., Wei A., Gong Z. Heat shock proteins: Dynamic biomolecules to counter plant biotic and abiotic stresses. Int. J. Mol. Sci., 2019, vol. 20:5321, doi:10.3390/ijms20215321 
10. Morrow G., Hightower L.E., Tanguay R.M. Small heat shock proteins: big folding machines. Cell Stress and Chaperones, 2015, vol. 20, pp. 207-212, doi: 10.1007/s12192-014-0561-0

11. Bösl B., Grimminger V., Walter S. The molecular chaperone Hsp104 - a molecular machine for protein disaggregation. J. Struct Biol., 2006, vol. 156, pp. 139-148, doi: 10.1016/j.jsb.2006.02.004

12. Tang T., Yu A., Li P., Yang H., Liu G., Liu L. Sequence analysis of the Hsp70 family in moss and evaluation of their functions in abiotic stress responses. $\mathrm{Sci}$ Rep., 2016, vol. 6: 33650, doi: 10.1038/srep33650

13. Maestri E., Klueva N., Perrotta C., Gulli M., Nguyen H.T., Marmiroli N. Molecular genetics of heat tolerance and heat shock proteins in cereals. Plant Mol. Biol., 2002, vol. 48, pp. 667-681, doi: 10.1023/a:1014826730024

14. Borovik O.A., Grabelnych O.I. Mitochondrial alternative cyanide-resistant oxidase is involved in an increase of heat stress tolerance in spring wheat. Journal of Plant Physiology, 2018, vol. 231, pp. 310-317, doi: 10.1016/j. jplph.2018.10.007.

15. Dong S., Beckles D.M. Dynamic changes in the starch-sugar interconversion within plant source and sink tissues promote a better abiotic stress response. Journal of Plant Physiology, 2019, vol. 234-235, pp. 80-93, doi: 10.1016/j. jplph.2019.01.007

16. Mangelsen E., Kilian J., Harter K., Jansson C., Wanke D., Sundberg E. Transcriptome analysis of high-temperature stress in developing Barley caryopses: Early stress responses and effects on storage compound biosynthesis. Molecular Plant, 2011, vol. 4, pp. 97-115, doi: 10.1093/mp/ssq058

17. Su P., Jiang C., Qin H., Hu R., Feng J., Chang J., Yang G., He G. Identification of potential genes responsible for thermotolerance in wheat under high temperature stress. Genes (Basel), 2019, vol. 10(2):174, doi: 10.3390/genes10020174

18. Barnabás B., Jäger K., Fehér A., 2008. The effect of drought and heat stress on reproductive processes in cereals. Plant, Cell and Environ., 2008, vol. 31, pp. 11-38, doi: 10.1111/j.1365-3040.2007.01727.x

\section{DATA ABOUT THE AUTHORS}

Fedotova Olga Andreevna, Ph.D., Senior Researcher of the Laboratory of Physiological Genetics Siberian Institute of Plant Physiology and Biochemistry SB RAS 132, Lermontov Str., Irkutsk, 664033, Russian Federation ol.borovik@mail.ru; olgaborovik@sifibr.irk.ru SPIN-code: 3886-9838 
ORCID: 0000-0002-6276-5792

ResearcherID: I-7726-2018

Scopus Author ID: 52563279400

Polyakova Elizaveta Alekseevna, Graduate Studies of the Departments of Plant Physiology, Cell Biology and Genetics; Lead Engineer of the Laboratory of Physiological Genetics

Irkutsk State University; Siberian Institute of Plant Physiology and Biochemistry SB RAS

1, K. Marx Str., Irkutsk, 664003, Russian Federation; 132, Lermontov Str., Irkutsk, 664033, Russian Federation

polyackova.elizaveta727@mail.ru

SPIN-code: 4597-1310

ORCID: 0000-0002-4830-5888

Grabelnykh Olga Ivanovna, Dr. Sci. (Biology), Principal Research Scientist of the Laboratory of Physiological Genetics; Professor of the Departments of Plant Physiology, Cell Biology and Genetics

Siberian Institute of Plant Physiology and Biochemistry SB RAS; Irkutsk State University

132, Lermontov Str., Irkutsk, 664033, Russian Federation; 1, K. Marx Str., Irkutsk, 664003, Russian Federation

grolga@sifibr.irk.ru

SPIN-code: 1156-0511

ORCID: 0000-0003-4220-6608

ResearcherID: $R-5190-2016$

Scopus Author ID: 6602939392

\section{ДАННЫЕ ОБ АВТОРАХ}

Федотова Ольга Андреевна, кандидат биологических наук, старший научный сотрудник лаборатории физиологической генетики Федеральное государственное бюджетное учреждение науки Сибирский институт физиологии и биохимии растений Сибирского отделения Российской академии наук (СИФИБР СО РАН) ул. Лермонтова, 132, г. Иркутск, 664033, Российская Федераиия ol.borovik@mail.ru; olgaborovik@sifibr.irk.ru

Полякова Елизавета Алексеевна, магистрант; ведущий инженер лабо- 
ратории физиологической генетики

Федеральное государственное бюджетное образовательное учреждение высшего образования «Иркутский государственный университет» (ФГБОУ ВО «ИГУ»); Федеральное государственное бюджетное учреждение науки Сибирский институт физиологии и биохимии растений Сибирского отделения Российской академии наук (СИФИБР СО РАН)

ул. Карла Маркса, 1, г. Иркутск, 664003, Российская Федерачия; ул. Лермонтова, 132, г. Иркутск, 664033, Российская Федерачия polyackova.elizaveta727@mail.ru

Грабельных Ольга Ивановна, доктор биологических наук, главный научный сотрудник лаборатории физиологический генетики; профессор кафедры Физиологии растений, клеточной биологии и генетики Федеральное государственное бюджетное учреждение науки Сибирский институт физиологии и биохимии растений Сибирского отделения Российской академии наук (СИФИБР СО РАН); Федеральное государственное бюджетное образовательное учреждение выстего образования «Иркутский государственный университет» (ФГБОУ ВО «ИГУ»)

ул. Лермонтова, 132, г. Иркутск, 664033, Российская Федерация; ул. Карла Маркса, 1, г. Иркутск, 664003, Российская Федеращия grolga@sifibr.irk.ru 